\title{
Morphological and genetic characterization among wild populations of copao (Eulychnia acida Phil.), cactus endemic to Chile
}

\author{
Constanza Jana ${ }^{1 *}$, Angélica Salvatierra ${ }^{1}$, Daysi Dỉaz, and Lucía Martinez ${ }^{1}$
}

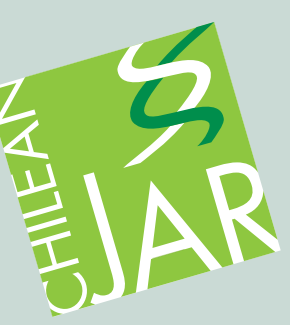

\section{ABSTRACT}

There are endemic cacti species in the North of Chile with edible fruits and a fledgling productive potential, with unknown degree diversity. Low diversity compromises the ability of populations to evolve and reduces their chances of survival under environmental changes. Copao (Eulychnia acida Phil.), a cactus endemic to Chile that grows in the Coquimbo Region ( $30^{\circ} \mathrm{S}$ lat) and able to bear fruit in water stress conditions, were morphologically characterized using descriptors of other columnar cacti at three different locations where it usually grows wild. Five inter simple sequence repeat (ISSR) primers, which were reported for other cacti that produced replicable and informative amplifications, were selected for the genetic characterization. Statistical analysis was performed to describe the diversity of this species and morphological and genetic results compared each other. High variation was observed between and within the evaluated populations for parameters of central tendency, dispersion, and univariate statistical analysis of the morphological traits. Principal component analysis showed that $73 \%$ of the population variation at the three locations could be explained by the first three principal components with $34 \%, 22 \%$, and $17 \%$ of the observed variation, respectively. The five ISSR primers generated 7 to 11 polymorphic bands with a band range between 100 and $1517 \mathrm{bp}$. The polymorphic information content (PIC) averaged 0.75 , which suggests high diversity between and within populations. Consensus of $85 \%$ existed between the selected descriptors and the ISSR markers, which points them out as suitable tools to analyze diversity in this species.

Key words: Copao, descriptors, generalized procrustes analysis (GPA), genetic and morphological characterization, inter simple sequence repeat (ISSR).

${ }^{1}$ Instituto de Investigaciones Agropecuarias, INIA Intihuasi, Colina San Joaquín, La Serena, Chile. "Corresponding author (cjana@inia.cl).

Received: 15 September 2016

Accepted: 4 February 2017.

doi:10.4067/S0718-58392017000100001

\section{INTRODUCTION}

In times of climate change are necessary species able to survive to changing conditions. Ability to adapt when the environment changes, is the result of their genetic diversity, condition that needs to be studied. Insufficient diversity would lead species to restrict their geographic distribution and be more vulnerable to extinction under novel selection pressure (Sheth and Angert, 2014). Small populations with low diversity might also experience higher levels of inbreeding (Oleas et al., 2014).

Copao or rumpa (Eulychnia acida Phil.) is an arborescent cactus native to Chile and endemic in the Atacama and Coquimbo Regions. The species has achieved importance in the Coquimbo Region given the recurrent periods of water scarcity, such as in the last $10 \mathrm{yr}$; it is distributed from $29^{\circ}$ to $32^{\circ} \mathrm{S}$ lat from the coast to $1200 \mathrm{~m}$ a.s.l. in an East-West direction. It primarily grows on North-exposed slopes that cover an area of approximately 350000 ha and the density of wild populations is not known.

The fruit of this species is edible and contains minerals, vitamin C (Masson et al., 2011), and antioxidants with antiinflammatory properties (Jiménez-Aspee et al., 2014; 2015). The functional properties of its fruit, in addition to the water stress adaptation of the species, make it an ideal productive alternative in arid zones. This is not the only fruit of the genus Eulychnia that can be consumed; both E. breviflora and E. castanea are found in the coastal zones (Hoffmann and Walter, 2004). However, fruits of these three species are clearly differentiated.

Copao grows in the wild and coexists with the abovementioned species in the coastal zone or with Echinopsis sp. in the highlands; there has been no domestication process, with the exception of plantation management for fence-building using stems collected from existing populations. Morphological variability has been observed in these species in both the fruit and plant. Throughout the distribution area fruit exhibit different epicarp colors and shapes, from green to red and round to conical, along with variations in plant spine and rib size.

The flower also has different pericarpel and receptacle sizes. Hoffmann and Walter (2004) described differences in flowers and fruits and expressed the need for further study and characterization of the different shapes they found. It has also been observed that there is a variation in antioxidant activity and characterization of constituents among copao fruits produced in the two valleys of the Coquimbo Region: Elqui Valley and Limarí Valley (Jiménez-Aspee et al., 2014; 2015). This variability can be a phenotypic response influenced by 
the natural environmental conditions where this species grows, or it has a genetic base favored by the apparent compatibility of its sexual reproduction system with closely related species.

Variability must be characterized in both cases because it is the basis for understanding and identifying desirable attributes and domesticating the species through the selection and multiplication of promising individuals from the agronomic standpoint. One of the most commonly used methodologies to describe species is morphological characterization using defined descriptors that taxonomically differentiate plants (Bianco et al., 2011). These descriptors must be easily and rapidly measured; they refer to shape, structure, or behavior of an accession (Hernández-Villareal, 2013). They are usually highly heritable traits that can be easily detected at a glance and are equally expressed in all environments (Franco and Hidalgo, 2003). So far, no morphological descriptors have been defined for E. acida; the descriptors proposed by the International Organizations for Succulent Plant Research (IOS) for other cactuses are inadequate according to Hoffmann and Walter (2004). Molecular markers are used because morphological traits are sensitive to environmental influence; these markers directly reveal polymorphisms at the DNA level and are a powerful tool to clarify genetic diversity and evaluate relationships among genotypes (Tao et al., 2014). Among these, the inter simple sequence repeat (ISSR) molecular markers are related to a genetic marker that allows obtaining levels of variation in genomic DNA fragments, particularly nuclear ones. These regions consist of tandem repeats of simple patterns such as (CT)n or (CA)n located between non-repetitive sequences of the eukaryotic nuclear genome (Zietkiewicz et al., 1994). They are widely used for genetic diversity studies in many plants (Ferreira et al., 2010; Bianco et al., 2011; Almajali et al., 2012; Tao et al., 2014). However, no reports exist of their application in the germplasm of the species of the genus Eulychnia. The advantages of this technique are that it detects high variation, is reproducible, does not need high DNA concentrations, and it is not necessary to know the genome sequence of the organism to design primers (Bornet and Branchard, 2001).
When different characterization systems are used, it is necessary to seek consensus between systems, one of these methods is Generalized Procrustes Analysis (GPA). Bramardi et al. (2005) studied a collection of cucumber cultivars with genetic and morphological characterization and this method proved to be superior to other methods for characterizing plant germplasm.

The main objectives of this study were the morphological and genetic characterization of copao or rumpa populations at different locations in the Coquimbo Region, Chile, where it is usually a wild species, and determine if genetic variability exists between and within locations. We also evaluated the potential of morphological traits and ISSR markers as descriptors, and compared the two characterization systems being used.

\section{MATERIALS AND METHODS}

\section{Description of the geographical area where wild population of copao are found}

Three locations in the Elqui and Limarí Valleys in the drylands of the Coquimbo Region were selected to conduct this study: San Carlos (30³5' S, 7080’ W; $634 \mathrm{~m}$ a.s.1.), Oruro (30³8' S, 71 $32^{\prime}$ 'W; $257 \mathrm{~m}$ a.s.1.), and Manquehua (30 $95^{\prime} \mathrm{S}, 71^{\circ} 15^{\prime} \mathrm{W}$; $704 \mathrm{~m}$ a.s.1.). San Carlos has 15.4 ${ }^{\circ} \mathrm{C}$ annual mean temperature and $29.9 \mathrm{~mm}$ rainfall; Oruro has $14.9{ }^{\circ} \mathrm{C}$ annual mean temperature, is the driest with $76.7 \mathrm{~mm}$ rainfall, and Manquehua has $7.7{ }^{\circ} \mathrm{C}$ annual mean temperature and $90.7 \mathrm{~mm}$ rainfall.

Soils at these three locations have similar N, P, and K levels, low soil porosity $(<50 \%)$, and medium textures, with the exception of Oruro, which has a clay texture. The main differences are in Na content, which is higher in Oruro (Table 1).

\section{Morphological characterization of copao}

Three sectors of $1000 \mathrm{~m}^{2}$ from each location were evaluated; five individuals were identified as representative of the sector population. Mean plant density of each location was 470, 174 and 523 plants ha $^{-1}$ for San Carlos, Manquehua and Oruro, respectively.

Table 1. Soil analysis results of three locations in the Coquimbo Region where wild copao populations were characterized in 2013.

\begin{tabular}{|c|c|c|c|c|c|c|c|c|}
\hline Location & $\mathrm{N}$ & $\mathrm{P}$ & $\mathrm{K}$ & $\mathrm{Na}$ & Sand & Silt & Clay & TC \\
\hline & $\longrightarrow$ & $\mathrm{mg} \mathrm{kg}^{-1}$ & - & meq $100 \mathrm{~g}^{-1}$ & $\longrightarrow$ & $-\%-$ & - & \\
\hline $\mathrm{SC}$ & $30.7 b$ & $14.0 \mathrm{a}$ & $126.0 \mathrm{a}$ & $0.15 b$ & $47.0 \mathrm{a}$ & $35.3 \mathrm{a}$ & $17.7 \mathrm{a}$ & $\mathrm{La}$ \\
\hline MQ & $35.3 \mathrm{ab}$ & $21.0 \mathrm{a}$ & $90.7 \mathrm{a}$ & $0.10 \mathrm{~b}$ & $52.3 \mathrm{a}$ & $20.0 \mathrm{~b}$ & $27.7 \mathrm{a}$ & SCLa \\
\hline ORU & $36.0 \mathrm{a}$ & $13.0 \mathrm{a}$ & $93.7 \mathrm{a}$ & $0.40 \mathrm{a}$ & $46.3 \mathrm{a}$ & $22.7 b$ & $30.0 \mathrm{a}$ & $\mathrm{Cb}$ \\
\hline $\mathrm{CV}$ & 7.5 & 33.1 & 35.1 & 40.60 & 18.1 & 15.8 & 37.6 & 15.7 \\
\hline \multirow[t]{2}{*}{ Location } & $\mathrm{AD}$ & RD & $\mathrm{FC}$ & PWP & AM & TP & MiP & $\mathrm{MaP}$ \\
\hline & 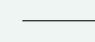 & 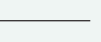 & & 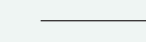 & & $-\%-$ & 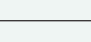 & 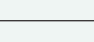 \\
\hline $\mathrm{SC}$ & $1.4 \mathrm{~b}$ & $2.6 \mathrm{a}$ & $12.3 \mathrm{a}$ & $5.3 \mathrm{a}$ & $6.9 \mathrm{a}$ & $35.0 \mathrm{a}$ & $17.6 \mathrm{~b}$ & $27.3 \mathrm{a}$ \\
\hline MQ & $1.5 \mathrm{a}$ & $2.6 \mathrm{a}$ & $16.6 \mathrm{a}$ & $7.5 \mathrm{a}$ & $8.8 \mathrm{a}$ & $40.6 a$ & $25.6 \mathrm{ab}$ & $15.0 \mathrm{~b}$ \\
\hline ORU & $1.6 \mathrm{a}$ & $2.6 \mathrm{a}$ & $17.7 \mathrm{a}$ & $9.3 \mathrm{a}$ & $8.3 \mathrm{a}$ & $39.3 \mathrm{a}$ & $28.0 \mathrm{a}$ & $11.3 \mathrm{~b}$ \\
\hline $\mathrm{CV}$ & 3.4 & 1.8 & 21.3 & 27.4 & 22.7 & 22.4 & 19.2 & 22.5 \\
\hline
\end{tabular}

Different letters in the same column indicate significant difference according to Duncan's test $(\mathrm{p}<0.05)$.

SC: San Carlos, MQ: Manquehua, ORU: Oruro, TC: textural class, AD: bulk density, RD: real density, FC: field capacity, PWP: permanent wilting point, AM: available moisture, TP: total porosity, MiP: microporosity, MaP: macroporosity.

For the textural class (TC) quantitative data were transformed to texture reference (L: loam, SCL: sandy clay loam, C: clay). 
Given that there are no phenotypic descriptors of copao, morphological characterization was based on the methodology proposed for other columnar cacti (RosalesBustamante et al., 2009; Campos-Rojas et al., 2011), including 12 plant quantitative variables, 14 flower variables (nine quantitative and five qualitative), and 14 fruit morphological variables (ten quantitative and four qualitative). The morphological evaluations were carried out on three stems from each plant. To evaluate variables in the flower and fruit, five flowers and three fruits, respectively, were harvested per plant in each sector at the three locations. Variables related to the age of the plant (plant height, stem diameter) were analyzed as covariates. The following were evaluated among the morphological variables: plant height $(\mathrm{m})$, stem diameter $(\mathrm{cm})$, distance from the ground of the first branch $(\mathrm{cm})$, canopy diameter $(\mathrm{m})$, number of ribs, areole length $(\mathrm{mm})$, areole width $(\mathrm{mm})$, number of areoles per area (estimated in $10 \mathrm{~cm}^{2}$ ), presence or absence of trichomes, number of spines per areole, length of longest spine $(\mathrm{mm})$, and length of shortest spine $(\mathrm{mm})$. The evaluated traits in the flowers were perianth length $(\mathrm{mm})$, flower length $(\mathrm{mm})$, flower diameter $(\mathrm{mm})$, carpel length $(\mathrm{mm})$, outer sepal dominant color, presence or absence of spines on pericarpel scales, presence or absence of trichomes on pericarpel scales, number of inner sepals, number of outer sepals, style length $(\mathrm{mm})$, inner sepal dominant color, number of scales $\mathrm{cm}^{-2}$, pericarpel color, and pericarpel base width (mm) (Figure 1a). A color table was made for the inner sepal dominant color because only four color categories were observed in all the evaluated flowers (Figure 1b). The evaluated traits in fruits were polar diameter $(\mathrm{cm})$, equatorial diameter $(\mathrm{cm})$, length/width ratio, fruit shape, fruit weight $(\mathrm{g})$, husk weight $(\mathrm{g})$, pulp weight $(\mathrm{g})$, husk thickness $(\mathrm{mm})$, pulp thickness $(\mathrm{mm})$, pericarpel scale color, presence and pericarpel scale villi color, number of scales $\mathrm{cm}^{-2}$ (Figure 2a), fruit color (Figure 2b), and fruit sugar content $\left({ }^{\circ} \mathrm{Brix}\right)$.

\section{Molecular characterization of copao}

Three DNA extraction protocols proposed by Lodhi et al. (1994), Keb-Llanes et al. (2002), and Cota-Sánchez et al. (2006) were tested for recalcitrant species extraction because no specific extraction protocol existed for copao. Once the three protocols were evaluated, the protocol based on the use of cetyltrimethylammonium bromide (CTAB) detergent (Lodhi et al., 1994) was selected and specific modifications described by Cota-Sánchez et al. (2006) were included; in the final stage, the pellet was resuspended in $50 \mu \mathrm{L}$ TE buffer and incubated at $37^{\circ} \mathrm{C}$ for $30 \mathrm{~min}$ and at $42^{\circ} \mathrm{C}$ for $15 \mathrm{~min}$.

Five samples from each of the three sectors were collected and an additional sample of Eulychnia breviflora Phil. as an external group. Samples were pieces of healthy stem from each plant removed with a cork borer, which were immediately frozen in liquid nitrogen. The quality and integrity of the extracted DNA was analyzed by
Figure 1. Flowers's characteristic of copao, evaluated in this study. a) General characteristic b) inner sepal dominant color of copao flower.
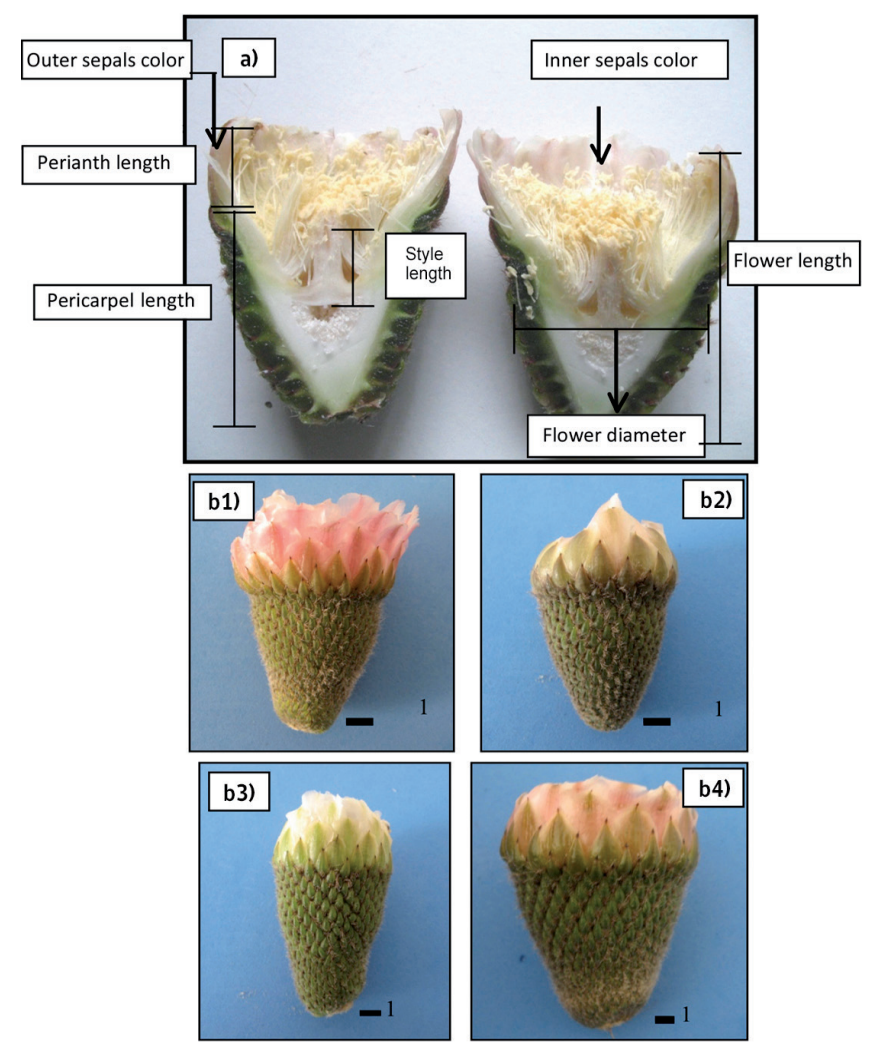

electrophoresis in $0.8 \%$ agarose gel in $0.5 \mathrm{X}$ TAE buffer, and DNA was visualized in a UV transilluminator by staining it with GelRed dye. The concentration and purity of the DNA was determined by absorbance at $260 / 280 \mathrm{~nm}$ by spectrophotometry (NanoDrop ND-100; Thermo Fisher Scientific, Wilmington, Delaware, USA).

A total of 19 primers were selected from other successful cactus species, that is, Opuntia spp. (Luna-Paez et al., 2007) and Ferocactus histrix (Castro-Félix et al., 2008). The amplification program was specified for each primer. For markers described by Luna-Paez et al. (2007), the program was $94{ }^{\circ} \mathrm{C}$ for $1 \mathrm{~min}, 94^{\circ} \mathrm{C}$ for $30 \mathrm{~s}$, each primer annealing temperature for $30 \mathrm{~s}, 72{ }^{\circ} \mathrm{C}$ for $1.5 \mathrm{~min}$ for a total of 35 cycles, and a final extension at $72{ }^{\circ} \mathrm{C}$ for 2.5 min. The program for Castro-Félix et al. (2008) was $95{ }^{\circ} \mathrm{C}$ for $3 \mathrm{~min}, 95{ }^{\circ} \mathrm{C}$ for $1 \mathrm{~min}$, each primer annealing temperature for $1 \mathrm{~min}, 72{ }^{\circ} \mathrm{C}$ for $2 \mathrm{~min}$ for a total of 40 cycles, and a final extension at $72{ }^{\circ} \mathrm{C}$ for $7 \mathrm{~min}$. The polymerase chain reactions (PCRs) were programmed in a Tempra thermocycler. The amplicons were visualized by electrophoresis in $1.5 \%$ and $2 \%$ agarose gels stained with GelRed (Biotium Corporate, Fremont, California, USA); they were run in a horizontal gel electrophoresis unit (HU 10 mini-plus horizontal, Scie-Plas, Southam, UK) and photographed with a built-in PowerShot G12 camera (Canon, Tokyo, Japan). The electrophoretic run was for 35 $\min$ at $140 \mathrm{~V}$. 
Figure 2. Fruit characteristic of copao found in Coquimbo Region. a) Details of fruit scale density, number of scales $\mathrm{cm}^{-2}$. b). Diversity of Eulychnia fruit colors in pulp and pericarpel.
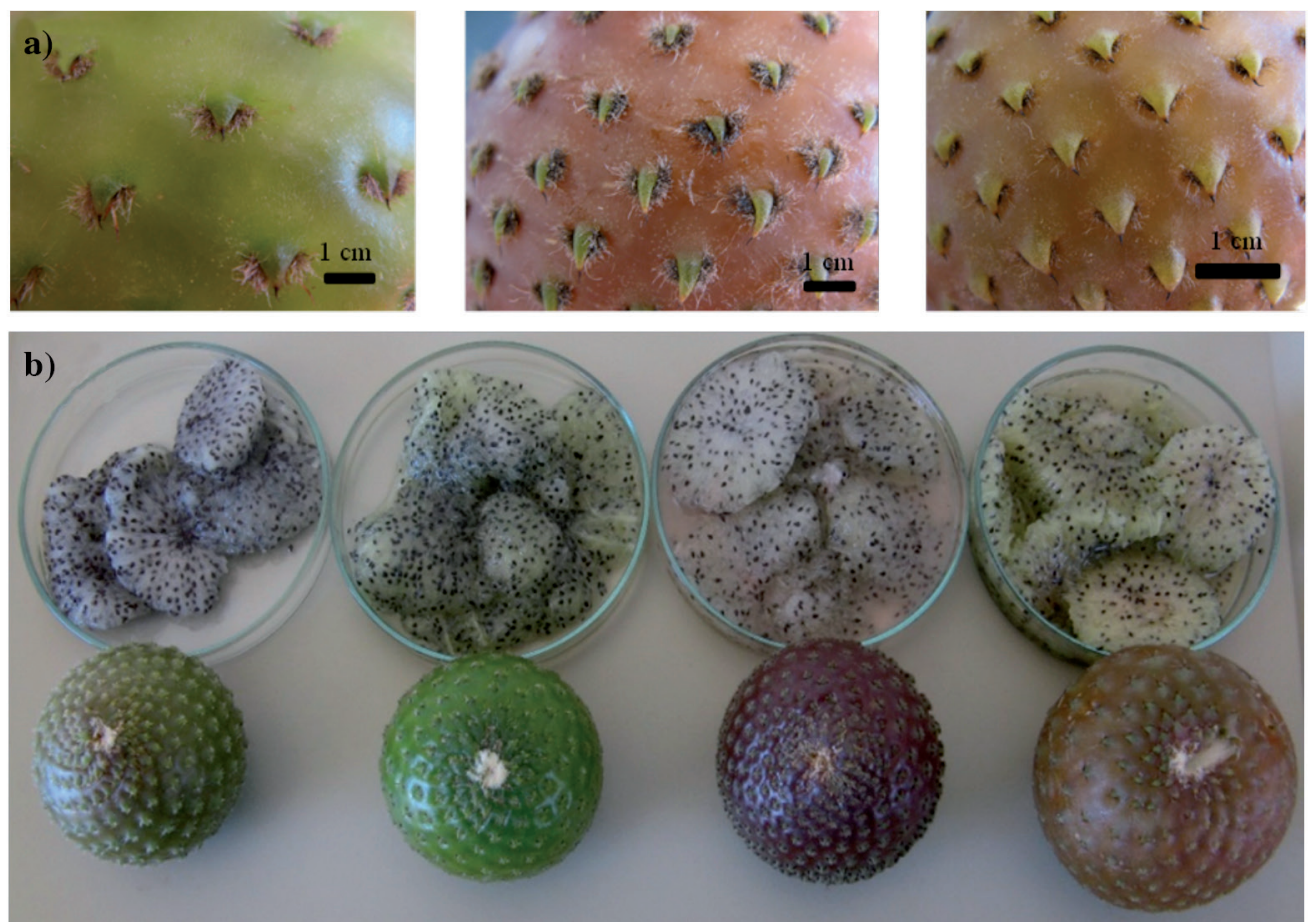

\section{Statistical analysis}

All the quantitative variables were subjected to statistical parameters of central tendency and dispersion. A completely randomized experimental design was used to estimate variability at each location where the experimental unit consisted of sectors that included five plants for each location. An ANOVA was performed as well as a mean separation test (Duncan $\mathrm{p}<0.05$ and $\mathrm{p}<0.01$ ) with Statgraphics Centurion XVII software (Statgraphics, Warrenton, Virginia, USA).

Variable categories were fruit shape (pear-shaped, round, and oval) and presence and pericarpel villi color (without scales or without villi, white, brown, crystalline, and yellow), which were analyzed in the populations at the three locations by generalized linear models (SPSS 17.0; SPSS Inc., Chicago, Illinois, USA); the significant differences were tested according to Duncan's new multiple range test (DMRT) at $\mathrm{p}<0.05$. A Munsell Plant Tissue Color Chart (Munsell Color, 1977) was used in the evaluations; however, the Royal Horticultural Society Colour Chart (Royal Horticultural Society, 2014) was used for inner sepal color.

To explain the genetic diversity between locations and establish relationships among different sectors and different analyzed traits, Gower's coefficient was estimated; this allows expressing the similarity among samples that are characterized by different types of markers, that is, continuous and discrete variables, by the following formula:

$$
S_{i j}=\frac{\sum_{c=1}^{m} W_{i j c} S_{i j c}}{\sum_{K=1}^{p} W_{i j c}}
$$

where $S_{i j}$ is the similarity between the ${ }^{\text {th }} i^{\text {th }}$ and $j^{\text {th }}$ sample or entity, $m$ is the number of observed variables or markers, and $W_{i j c}$ is the weighted $c^{\text {th }}$ variable in the $i^{\text {th }}$ and $j^{\text {th }}$ entity.

If the $c^{\text {th }}$ variable is binary or qualitative, the similarity between the $i$ and $j$ entity for the variable $c\left(S_{i j c}\right)$ is equal to 0 when the data between the $i^{\text {th }}$ (xi) and $j^{\text {th }}$ object are different; similarity is equal to 1 if they are the same. For a quantitative variable where $r c$ is the range of the variable $c$, similarity for the attribute $c$ is:

$$
S_{i j c}=1 \frac{\left|x_{i c}-x_{j c}\right|}{r_{c}}
$$

Orthogonal variables were then derived by principal component analysis (PCA) to interpret joint relationships, populations by location, and morphological variables (Di Rienzo et al., 2008). To visualize variation patterns among active variables, a simple link algorithm was applied from the correlation matrix and relationships were established among the sectors by a dendrogram according to Ward's method. For genetic analysis, patterns of amplified fragments (bands) obtained with selected primers were visually analyzed to generate a data matrix from welldefined bands. These data were recorded as binary variables using 1 to indicate that the band was present and 0 if it was absent. Amplified bands in different individuals were identified as identical if they had the same molecular weight. Based on these markers with a Jacquard distance matrix, a dendrogram was developed using UPGMA (unweighted pair-group method using an arithmetic average) cluster analysis.

Polymorphic information content (PIC) for each selected primer was calculated by the formula described by RoldánRuiz et al. (2000):

$$
P I C_{i}=2 f_{i}\left(1-f_{i}\right)
$$


where $P I C_{i}$ is the polymorphic information content of primer $i, f_{i}$ is the frequency of the bands that are present, and $\left(1-f_{i}\right)$ is the frequency of the absent bands.

Statistical analysis was performed with the InfoStat v6.0 program (Universidad Nacional de Córdoba, Córdoba, Argentina); a multivariate analysis of conglomerates was done using Ward's method and UPGMA cluster analysis.

Finally, to investigate the correlation between the morphological traits and the ISSR data, generalized procustes analysis (GPA) with the Infostat v6.0 software was used; GPA is a statistical tool based on standardized matrix notations and consensus arrangements among individuals and provides information about the harmonization or adaptation of the configurations produced by each set of variables. The most used method, simple matching coefficient is simple, but there is loss of information when there is no uniformity within the cultivar (neither 0 or 1 ) like this study. Gower's general coefficient is deal with mixed type of variables as in our case (Bramardi et al., 2005).

\section{RESULTS}

\section{Morphological traits of copao in Coquimbo Region}

For the 12 morphological variables (Table 2), the presence or absence of trichomes was eliminated from the analysis because they were not observed in any of the evaluated plants. Significant differences $(\mathrm{p}<0.01)$ among the populations at the three locations were observed in the quantitative traits, distance to the first branch, canopy diameter, areole length and width, number of areoles per area, and length of the longest spine. However, for stem diameter, number of ribs, and number of spines per scale, the difference was smaller but significant $(p<0.05)$. Most evaluated variables exhibited high variability at the three locations; it was calculated as the coefficient of variation (CV). The highest $\mathrm{CV}$ values were found for the length of the shortest spine $(80.05 \%)$, stem diameter $(79.73 \%)$, and areole length and width (65.17\% and $63.21 \%$, respectively).

For the flower trait categories, presence or absence of spines and trichomes in the pericarpel scales were eliminated from the analysis because they exhibited no variation in any of the evaluated plants; there were no spines in any of the plants and all the pericarpel scales showed trichomes. This confirms that all the fruits were related to E. acida and not to E. breviflora or E. castanea; these two species coexist with E. acida and their fruits have villi or spines on their scales. As for the nine quantitative variables, flower length and number of inner sepals exhibited significant differences $(\mathrm{p}<0.01)$ among the populations at the three locations. The variables with the highest $\mathrm{CV}$ were the number of scales $\mathrm{cm}^{-2}(26.7 \%)$ and pericarpel base width $(28.9 \%)$. Finally, in the 10 fruit quantitative variables, only husk thickness and number of

Table 2. Quantitative traits of copao populations at three locations in the Coquimbo Region.

\begin{tabular}{|c|c|c|c|c|c|c|c|}
\hline Morphological trait & Trait Code & Mean & SD & Min & Max & $\mathrm{CV}$ & Probability \\
\hline Height, m & $\mathrm{H}$ & 3.23 & 0.28 & 2.87 & 3.72 & 8.79 & \\
\hline Stem diameter, $\mathrm{cm}$ & $\mathrm{SD}$ & 36.40 & 29.03 & 11.78 & 90.25 & 79.73 & $*$ \\
\hline Distance to the $1^{\text {st }}$ branch, $\mathrm{cm}$ & DFB & 27.22 & 9.45 & 13.00 & 36.80 & 34.71 & $* *$ \\
\hline Canopy diameter, $\mathrm{m}$ & $\mathrm{CD}$ & 4.58 & 1.48 & 2.41 & 6.55 & 32.24 & $* *$ \\
\hline Number of ribs & NR & 11.71 & 0.34 & 11.07 & 12.13 & 2.94 & $*$ \\
\hline Areole length, mm & AL & 6.12 & 3.99 & 0.94 & 11.33 & 65.17 & $* *$ \\
\hline Areole width, mm & AW & 5.33 & 3.37 & 0.85 & 9.17 & 63.21 & $* *$ \\
\hline Areoles per area & APA & 4.67 & 0.70 & 3.67 & 5.47 & 14.88 & $* *$ \\
\hline Number of spines per areole & NSPA & 10.98 & 1.63 & 8.73 & 13.93 & 14.87 & $*$ \\
\hline Length of longest spine, $\mathrm{cm}$ & LLS & 14.07 & 2.07 & 9.93 & 16.93 & 14.74 & $* *$ \\
\hline Length of shortest spine, $\mathrm{cm}$ & LSS & 2.37 & 1.90 & 0.51 & 5.13 & 80.05 & \\
\hline Perianth length, $\mathrm{cm}$ & PL & 20.66 & 1.62 & 18.50 & 22.90 & 7.85 & \\
\hline Complete flower length, mm & CFL & 53.88 & 6.62 & 46.80 & 65.90 & 12.28 & $* *$ \\
\hline Flower diameter, $\mathrm{mm}$ & FD & 34.58 & 2.12 & 31.40 & 37.70 & 6.13 & \\
\hline Carpel length, mm & CL & 27.31 & 1.76 & 25.40 & 30.80 & 6.46 & \\
\hline Number of inner sepals & NIS & 22.89 & 3.17 & 19.00 & 28.30 & 13.84 & $* *$ \\
\hline Number of outer sepals & NOS & 27.21 & 1.90 & 24.60 & 30.40 & 6.99 & \\
\hline Style length, mm & SL & 18.37 & 1.65 & 16.00 & 20.50 & 8.97 & \\
\hline Number of scales, $\mathrm{cm}^{-2}$ & NS & 3.63 & 0.97 & 2.77 & 5.85 & 26.72 & \\
\hline Pericarpel base width, mm & PBW & 12.53 & 3.63 & 7.80 & 21.10 & 28.98 & \\
\hline Fruit polar diameter, mm & FPD & 57.44 & 2.82 & 54.20 & 63.20 & 4.91 & \\
\hline Fruit equatorial diameter, $\mathrm{mm}$ & FED & 58.72 & 2.73 & 52.50 & 62.20 & 4.65 & \\
\hline Fruit length/width ratio & FLWR & 0.98 & 0.08 & 0.90 & 1.10 & 8.52 & \\
\hline Fruit weight, $\mathrm{g}$ & FW & 107.30 & 10.83 & 82.60 & 118.90 & 10.09 & \\
\hline Fruit husk weight, $g$ & FHW & 58.67 & 4.88 & 51.20 & 67.00 & 8.31 & \\
\hline Fruit pulp weight, g & FPW & 47.01 & 7.51 & 31.20 & 58.30 & 15.97 & \\
\hline Fruit husk thickness, mm & FHT & 6.19 & 0.37 & 5.60 & 6.60 & 5.96 & $* *$ \\
\hline Fruit pulp thickness, mm & FPT & 48.63 & 3.18 & 41.80 & 53.20 & 6.53 & \\
\hline Number of fruit scales, $\mathrm{cm}^{-2}$ & NFS & 2.33 & 0.35 & 1.82 & 2.85 & 15.02 & $* *$ \\
\hline Fruit sugar content, ${ }^{\circ}$ Brix & FSC & 3.31 & 1.28 & 2.60 & 6.70 & 38.66 & \\
\hline
\end{tabular}

*, **Significant at the 0.05 and 0.01 probability levels, respectively.

Min: minimum, Max: maximum, SD: standard deviation, CV: coefficient of variation. 
scales $\mathrm{cm}^{-2}$ exhibited highly significant differences $(\mathrm{p}<0.01)$ at the three locations. Sugar content $\left({ }^{\circ} \mathrm{Brix}\right)$ was the variable with the highest CV (38.6\%).

The flower variable categories were mostly polymorphic and exhibited more than two phenotypes in the evaluated copao populations (Table 3 ). Up to 11 or 12 phenotype categories were obtained for the outer sepal dominant color trait. The highest phenotype frequency for pericarpel color was light olive green in San Carlos while the dominant phenotype was olive and olive green in Manquehua and Oruro, respectively. For the outer sepal dominant color, more than $50.0 \%$ of the populations in San Carlos were light olive green and olive phenotypes; $61.4 \%$ of the Manquehua populations varied between the three dark olive brown, very dark grayish green, and very dusky red phenotypes while $65.7 \%$ of the Oruro population varied between the four dark olive green, dark grayish green, olive, and olive green phenotypes. Only four colors were observed for all the populations and the inner sepal dominant color exhibited differences in the Oruro populations with $80 \%$ white (RHS 155D) while the dominant phenotype in San Carlos and Manquehua was red pink 11 (RHS 51D).

The fruit variable categories (Table 4) are fewer in number than the flower categories, but most are highly polymorphic,

Table 3. Phenotypes and frequencies of evaluated flower qualitative traits of copao populations at three locations: San Carlos, Manquehua and Oruro.

\begin{tabular}{|c|c|c|c|c|c|c|}
\hline \multirow[b]{3}{*}{ Variables } & \multicolumn{6}{|c|}{ Locations } \\
\hline & \multicolumn{2}{|c|}{ San Carlos } & \multicolumn{2}{|l|}{ Manquehua } & \multicolumn{2}{|l|}{ Oruro } \\
\hline & Color & Frequency & Color & Frequency & Color & Frequency \\
\hline & & $\%$ & & $\%$ & & $\%$ \\
\hline \multirow[t]{6}{*}{ Pericarpel color } & Light olive green & 37.0 & Olive & 45.5 & Olive green & 43.8 \\
\hline & Olive green & 14.8 & Dark olive & 36.4 & Olive & 28.1 \\
\hline & Dark olive green & 14.8 & Olive green & 9.1 & Light olive green & 18.8 \\
\hline & Dark grayish green & 14.8 & Grayish green & 4.5 & Dark olive green & 6.3 \\
\hline & Dark olive & 11.1 & Dark olive green & 2.3 & Dark olive & 3.1 \\
\hline & Very dark grayish olive & 7.4 & Light olive green & 2.3 & & \\
\hline \multirow[t]{12}{*}{ Outer sepal dominant color* } & Light olive green & 33.3 & Dark olive brown & 38.6 & Dark olive green & 21.9 \\
\hline & Olive & 29.6 & Very dark grayish green & 11.4 & Dark grayish green & 18.8 \\
\hline & Dark olive & 14.8 & Very dusky red & 11.4 & Olive & 12.5 \\
\hline & Light olive & 11.1 & Olive green & 9.1 & Olive green & 12.5 \\
\hline & Olive green & 7.4 & Dark reddish red & 6.8 & Dusky red & 9.4 \\
\hline & Dark olive brown & 3.7 & Dark grayish olive & 6.8 & Light olive & 9.4 \\
\hline & & & Very dark grayish olive & 4.5 & Olive brown & 3.1 \\
\hline & & & Light olive green & 4.5 & Dark grayish brown & 6.3 \\
\hline & & & Olive brown & 2.3 & Light olive brown & 3.1 \\
\hline & & & Weak red & 2.3 & Dark red & 6.3 \\
\hline & & & Dark olive & 2.3 & Very dark gray & 3.1 \\
\hline & & & & & Dark grayish brown & 3.1 \\
\hline \multirow[t]{4}{*}{ Inner sepal dominant color } & RHS 51D (red pink 11) & 48.1 & RHS 51D (red pink 11) & 50.0 & RHS 155 D (white 60) & 81.2 \\
\hline & RHS 155 D (white 60) & 22.2 & RHS 48 C (red pink) & 39.0 & RHS 155 C (white 59) & 12.5 \\
\hline & RHS 48 C (red pink) & 14.8 & RHS 155 D (white 60) & 11.0 & RHS 48 C (red pink) & 3.1 \\
\hline & RHS 155 C (white 59) & 14.8 & RHS 155 C (white 59) & 0.0 & RHS 51D (red pink 11) & 3.1 \\
\hline
\end{tabular}

*** Significant at the 0.05 and 0.01 probability levels, respectively.

Table 4. Phenotypes and frequencies of copao fruit qualitative traits that were evaluated in the populations found at three locations in the Coquimbo Region.

\begin{tabular}{|c|c|c|c|c|c|c|}
\hline \multirow[b]{3}{*}{ Variables } & \multicolumn{6}{|c|}{ Locations } \\
\hline & \multicolumn{2}{|c|}{ San Carlos } & \multicolumn{2}{|c|}{ Manquehua } & \multicolumn{2}{|c|}{ Oruro } \\
\hline & Phenotype & Frequency & Phenotype & Frequency & Phenotype & Frequency \\
\hline & & $\%$ & & $\%$ & & $\%$ \\
\hline \multirow[t]{3}{*}{ Fruit shape } & Round & 42.8 & Round & 85.7 & Round & 88.2 \\
\hline & Pear-shaped & 28.6 & Pear-shaped & 7.1 & Oval & 11.8 \\
\hline & Oval & 14.3 & Oval & 7.1 & & \\
\hline \multirow[t]{4}{*}{ Fruit scale color ${ }^{* *}$} & Olive green & 16.7 & Grayish green & 42.8 & Olive green & 21.9 \\
\hline & Light olive green & 66.6 & Olive green & 21.4 & Light olive green & 18.8 \\
\hline & Pale yellowish green & 16.7 & Light olive green & 21.4 & Olive & 12.5 \\
\hline & & & Dark olive green & 14.4 & Dark olive green & 12.5 \\
\hline \multirow[t]{4}{*}{ Fruit scale villi color } & Crystalline & 66.6 & Brown & 60.0 & Brown & 64.7 \\
\hline & Yellow & 16.7 & Crystalline & 20.0 & White & 35.3 \\
\hline & Brown & 16.7 & White & 20.0 & Crystalline & 0.0 \\
\hline & White & 0.0 & Yellow & 0.0 & Yellow & 0.0 \\
\hline \multirow[t]{4}{*}{ Fruit color } & Pale olive & 33.3 & Grayish green & 86.0 & Grayish green & 52.9 \\
\hline & Olive & 33.3 & Dusky red & 14.0 & Light olive green & 47.1 \\
\hline & Olive gray & 16.6 & & & & \\
\hline & Light olive green & 16.6 & & & & \\
\hline
\end{tabular}

\footnotetext{
* ${ }^{* *}$ Significant at the 0.05 and 0.01 probability levels, respectively.
} 
with the exception of the Oruro populations for fruit shape and fruit scale villi color. Fruits in the San Carlos populations were mostly round with a light olive green fruit scale color, crystalline scale villi, and pale olive and olive fruit color. Fruits in the Manquehua populations were mainly pearshaped, grayish green fruit scale dominant color, brown scale villi color, and grayish green fruit color in $85.7 \%$ of the populations. Finally, fruit shape was mainly round in Oruro. Most of the populations exhibited olive green fruit scale color, brown fruit scale villi color, and grayish green fruit color.

Gower distance coefficients were calculated for the 28 quantitative variables; these varied between 0.08 and 0.90 with a mean of 0.45 (Figure 3 ). The nearest variable values were areole width with areole length with a distance of 0.08 ; the farthest values were fruit weight for all the plant morphological variables with distances between 0.83 and 0.99 . The trait dendrogram was divided into three main clusters (A, B, and C). The first cluster (A) separated fruit weight from the rest of the variables. The second cluster (B) separates four fruit traits (fruit pulp weight, fruit husk weight, fruit equatorial diameter, fruit polar diameter) and two flower traits (complete flower length and flower diameter) from the rest of the variables grouped in the third cluster $(\mathrm{C})$.

Principal component analysis showed that $73 \%$ of the variation in the populations at the three locations can be explained by the first three principal components (PC) with $34 \%, 22 \%$, and $17 \%$ of the observed variation, respectively. Distance to the first branch and canopy diameter positively influenced PC1 while the style length, pericarpel base width, number of fruit scales $\mathrm{cm}^{-2}$ and complete flower length, negatively influenced it (Figure 4). Five main traits represented PC2: stem diameter, areole length and width (positive), fruit husk thickness and perianth length (negative). Finally, PC3 was mainly influenced by fruit pulp thickness, fruit weight (positive) and number of scales $\mathrm{cm}^{-2}$ in the flower, length of lonest spine (negative).

Principal component analysis allowed separating the populations by evaluated morphological traits, which showed differences between the San Carlos populations and the Manquehua and Oruro populations by PC1 (Figure 4). The last two locations were similar for this component. The variables with the highest values explained the differences between Oruro-Manquehua and San Carlos were distance to $1^{\text {st }}$ branch, canopy diameter, number of ribs and number of spines per areole. The variables that explained this same difference, but with lower values, length of longest spine, complete flower length, pericarpel base width and number of fruit scales $\mathrm{cm}^{-2}$. Regarding PC2, a possible separation between Oruro and Manquehua is shown, but it is weaker than the separation between San Carlos and Oruro-Manquehua in PC1. The variables that allow separating these two populations in PC2 are canopy diameter and stem diameter, and to a lesser degree number of spines per areole and number of ribs.

The cluster of the three populations from each location (Figure 5) showed that the individuals of all the sectorspopulations were different with a cut-off at $48 \%$ within the populations as well as between them. Gower distance coefficients were calculated for the nine sectors at the three locations and these varied between 0.45 and 0.93 with a mean of 0.81 . The highest similarity was found in Oruro between two populations (2 and 3) (0.45), and the greatest difference was between the San Carlos populations as compared with the rest of the populations $(0.93)$. The cophenetic correlation was 0.973 .

\section{Molecular characterization of copao}

Only five sets of primers (ISSR 02, ISSR 06, ISSR 12, ISSR 8 , and ISSR 15) were consistently reproduced in different

Figure 3. UPGMA dendrogram of 28 qualitative and quantitative morphological traits used as descriptors in three wild copao populations in the Coquimbo Region.

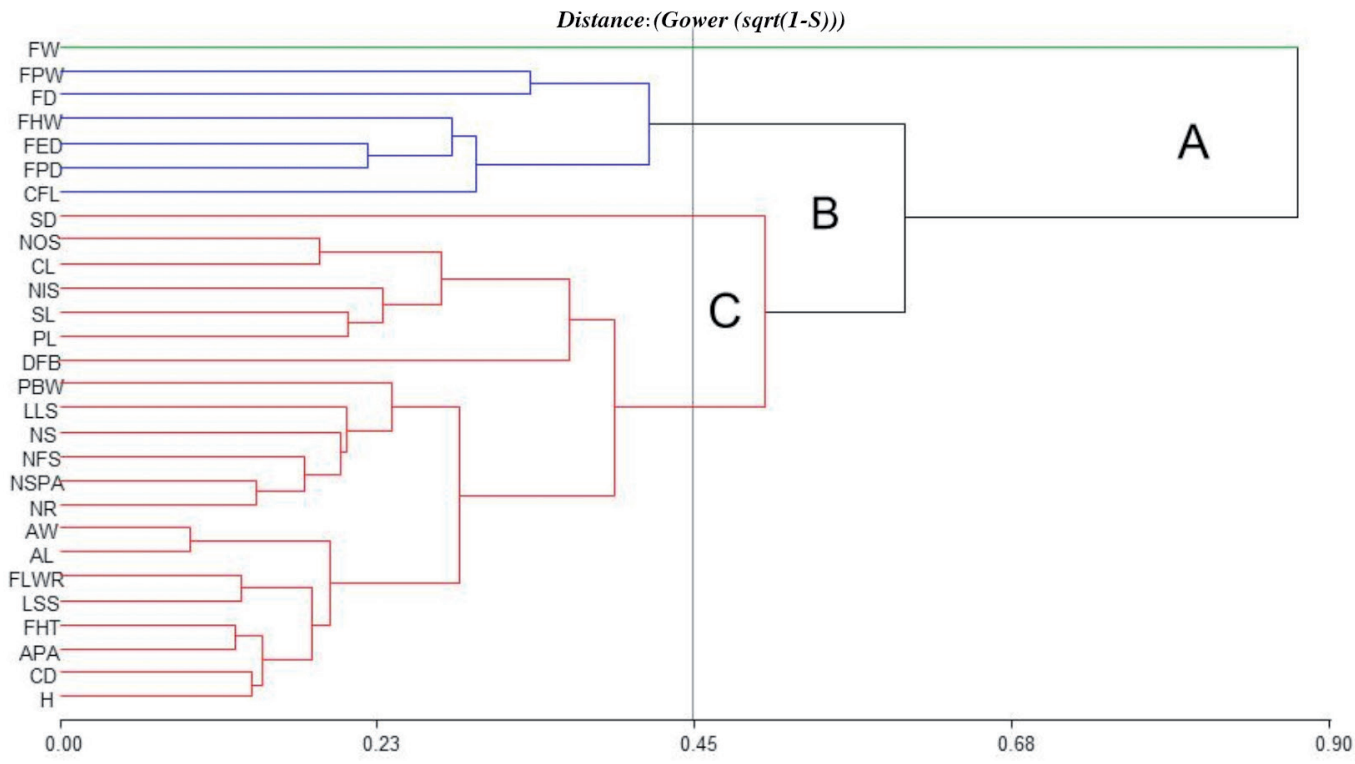

A, B, and C are clusters. Cophenetic correlation coefficient is 0.948 . 
Figure 4. Biplot of PC1 and PC2 with 28 standardized morphological variables and 9 sectors for the three populations by location.

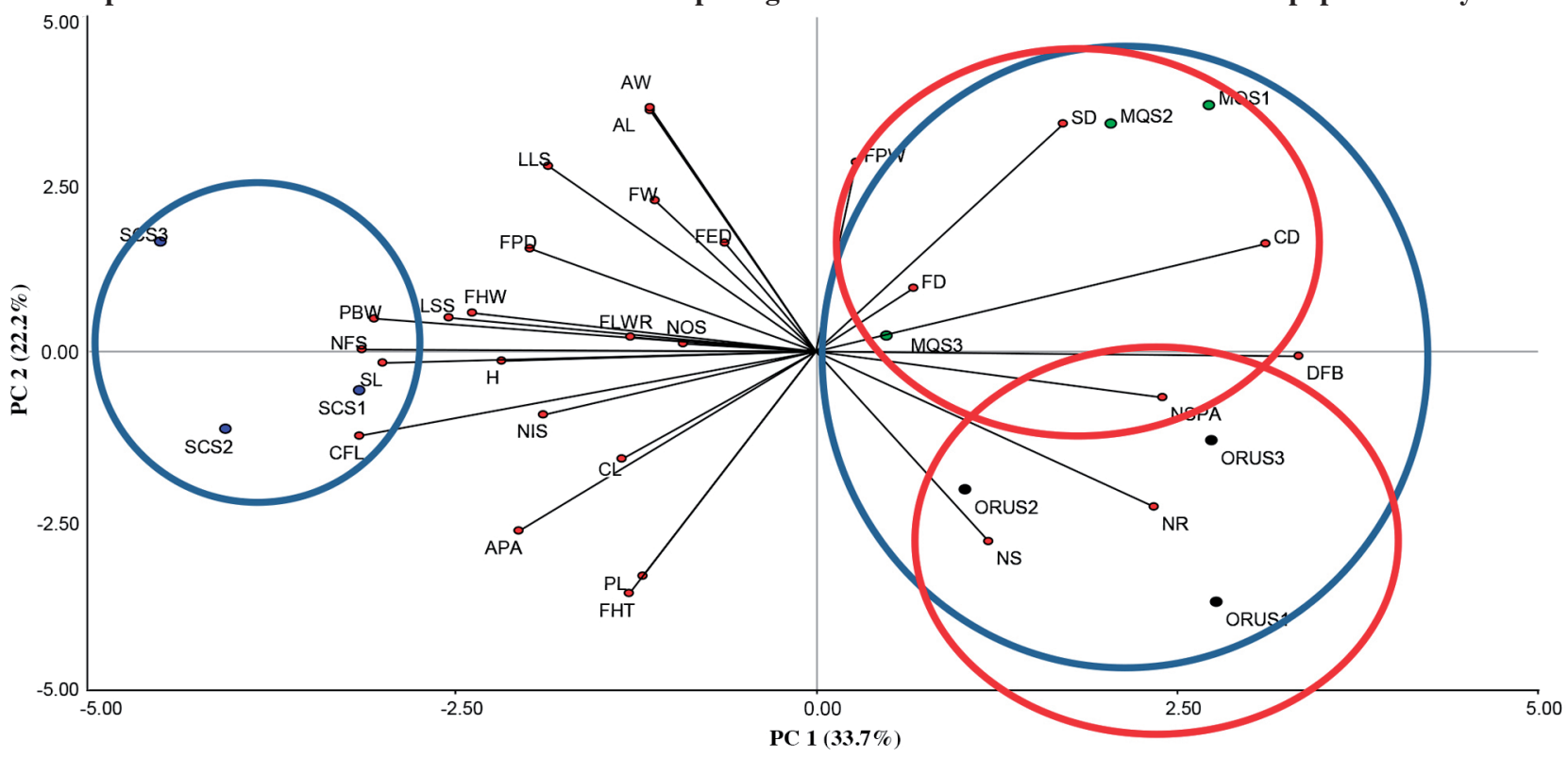

San Carlos = SC S1, SC S2, and SC S3, Oruro = ORU S1, ORU S2, and ORU S3, and Manquehua = MQ S1, MQ S2, and MQ S3.

Figure 5. Cluster analysis according to Ward based on Gower distance of 9 sectors for the three populations by location and 37 copao morphological traits.

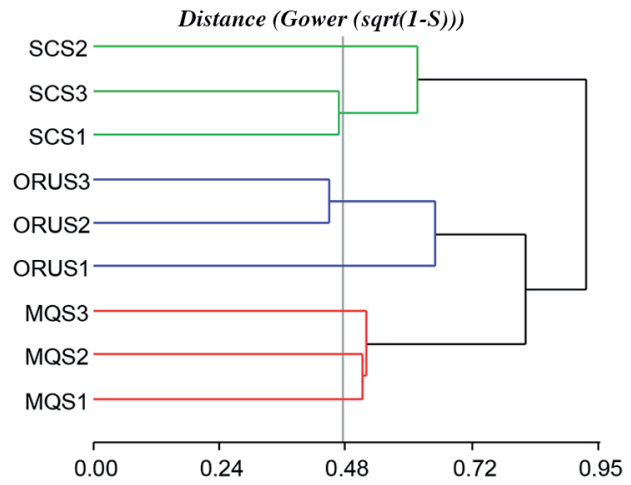

San Carlos = SC S1, SC S2, and SC S3, Oruro = ORU S1, ORU S2, and ORU S3, and Manquehua = MQ S1, MQ S2, and MQ S3.

PCR experiments and were included in the analysis. The five markers generated 47 reproducible and discriminatory amplicons resulting in a set of 39 polymorphic bands. Each marker generated from 7 (ISSR15) to 11 (ISSR02) identifiable bands. Band size ranged from 100 to $1517 \mathrm{bp}$, and the marker ISSR02 was the most polymorphic (Figure 6). Polymorphic information content varied between 0.59 and 0.96 with a mean of 0.75 , which suggests high genetic diversity among the evaluated populations and within them (Table 5). Dendrogram using UPGMA cluster analysis got a cophenetic ratio of 0.931 that indicates very good adjustment between the original distance matrix and cluster analysis. Only the individuals of San Carlos populations 2 and 3 are genetically similar, the rest of populations at the three locations are different, including the external group $E$. breviflora (Figure 7).

\section{Comparison of two systems: consensus}

Generalized Procrustes analysis was used with seven PCs of the morphological analysis (98\% total variability) and five principal coordinates (92\% total variability) (Figure 8). Variability was observed between and within populations. Populations in San Carlos were phenotypically and genetically different than individuals of the other populations and these differences were greater for San Carlos populations than the differences observed for individuals from Manquehua compared with Oruro. The consensus value between both analyses (Table 6) was 0.85 ; this means that a high consensus existed between the morphological and genetic descriptors.

\section{DISCUSSION}

\section{Morphological diversity of copao accessions in three wild populations}

Columnar cactus species usually cover vast geographical areas and exhibit high levels of genetic variation (Casas et al., 2007). In the few cases where these types of cacti cover confined areas, this variability is only partially maintained, for example, in Stenocereus eruca, which is an endemic species of the Sonoran Desert in Mexico (Clark-Tapia et al., 2005). The number of columnar cactus species in Chile is low as compared to Mexico or Argentina. However, Eulychnia is one the most diverse genera (Medel et al., 2010). Although there is no certainty, field observations indicate that this species is mainly sexually propagated, and the survival of its seed plantlets depends primarily on the adult plant that acts as a nurse plant for itself and other species (Cares et al., 2013). 
Figure 6. Inter simple sequence repeat (ISSR) profile for nine copao accessions at three locations, as well as an external sample of Eulychnia breviflora.

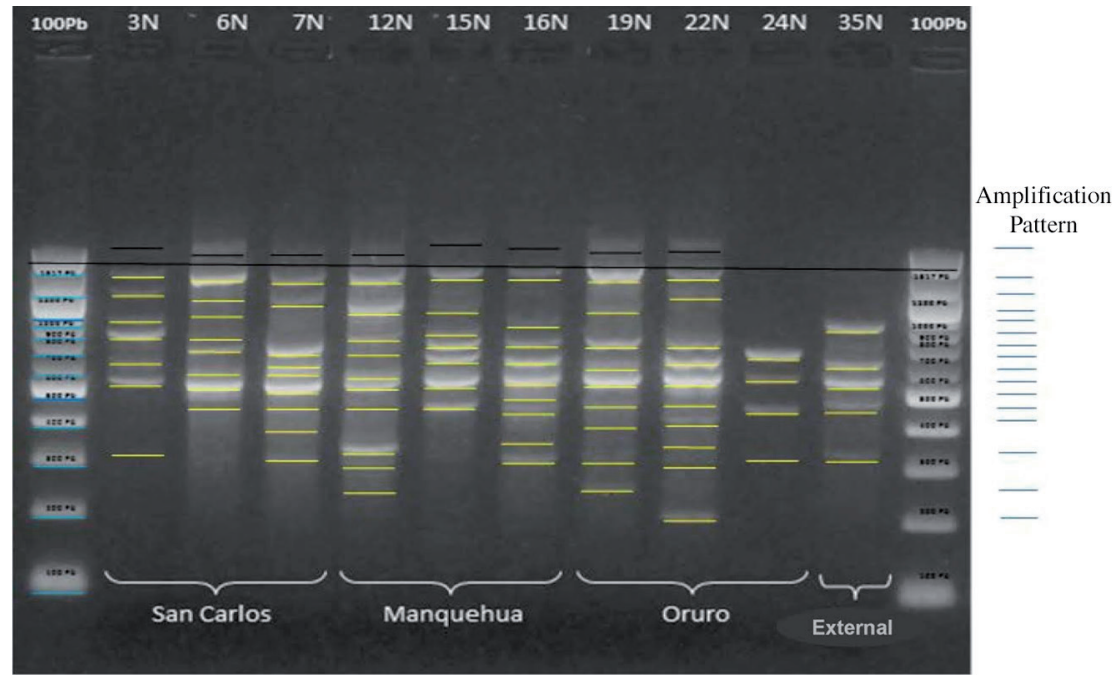

Primer ISSR02. 3N: SC1, 6N: SC2, 7N: SC3; 7N: MQ1, 12N; MQ 2, 15N: MQ 3; 19N: ORU1, 22N: ORU2, 29 N: ORU3, 35 N: external sample.

Table 5. Sequence of five designed inter simple sequence repeat (ISSR) primers with their optimal annealing temperature and amplification results in wild copao populations.

\begin{tabular}{|c|c|c|c|c|c|c|}
\hline Primer & Sequence ( $5^{\prime}$ to $\left.3^{\prime}\right)$ & $\begin{array}{l}\text { Annealing } \\
\text { temperature }\end{array}$ & $\begin{array}{l}\text { Total amplified } \\
\text { bands }\end{array}$ & $\begin{array}{c}\text { Number of } \\
\text { polymorphic bands }\end{array}$ & PPB & PIC \\
\hline & & ${ }^{\circ} \mathrm{C}$ & & & $\%$ & \\
\hline ISSR 02 & GACAGACAGACAGACAAC & 55 & 11 & 10 & 90.9 & 0.96 \\
\hline ISSR 06 & GAGAGAGAGAGAGAGAC & 56 & 10 & 8 & 80.0 & 0.92 \\
\hline ISSR 08 & CACACACACACACACACT & 48 & 10 & 7 & 70.0 & 0.76 \\
\hline ISSR 12 & GAGAGAGAGAGAGAGACA & 60 & 9 & 8 & 88.8 & 0.71 \\
\hline ISSR 15 & GAGAGAGAGAGAGAGACG & 60 & 7 & 6 & 85.7 & 0.59 \\
\hline Total & & & 47 & 39 & & \\
\hline Mean & & & 9.4 & 7.8 & 83.08 & 0.75 \\
\hline
\end{tabular}

PPB (\%): Percentage of polymorphic bands, PIC: polymorphic information content.

Figure 7. UPGMA dendrogram based on inter simple sequence repeat (ISSR) distances of nine sectors for the three populations of copao by location in Coquimbo Region.

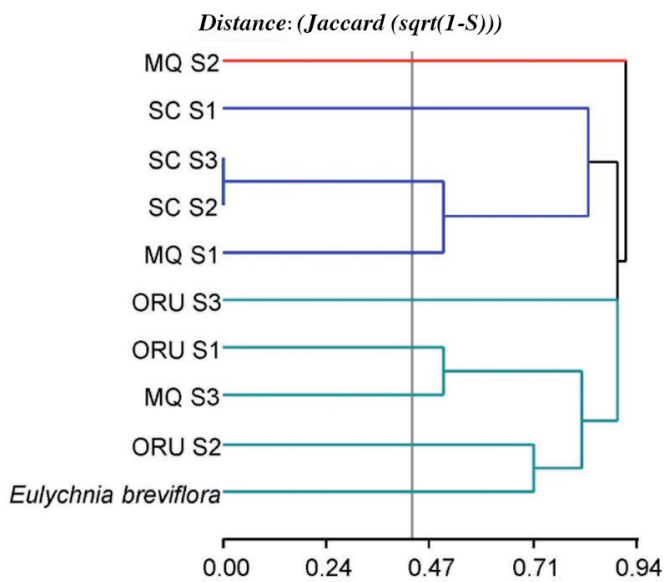

Cophenetic correlation coefficient is 0.931. San Carlos = SC S1, SC S2, and SC S3, Oruro = ORU S1, ORU S2, and ORU S3, and Manquehua = MQ S1, MQ S2, and MQ S3.
This study showed that copao germplasm, collected in three populations of the Coquimbo Region where it usually grows in the wild, is a source of high morphological variability. Highly significant differences were observed between and within populations for quantitative traits, especially for plant morphological traits, high CV values, and more than two phenotypic classes in the qualitative traits. This could be influenced by the type of observed propagation, seeds, cross-pollination, and the survival of other similar species, such as E. breviflora, E. castanea, or Echinopsis spp.

Although no specific information has been reported about the type of crossing in E. acida, columnar cacti generally show xenogamy (in which the ovules can only be fertilized by pollen from other plants) and pollination strongly associated with insects, birds, and mammals (Badano and Schlumpberger, 2001). Hoxey and Klaassen (2011) reported possible crossing between E. chorosensis and E. acida in the Llanos de Choros zone located at the boundary limits of the Coquimbo and Atacama Regions. Eulychnia chorosensis has flowers with a high number of dark hairs, which is not 
Figure 8. Consensus configuration between morphological and genetic descriptors used to study copao variability.

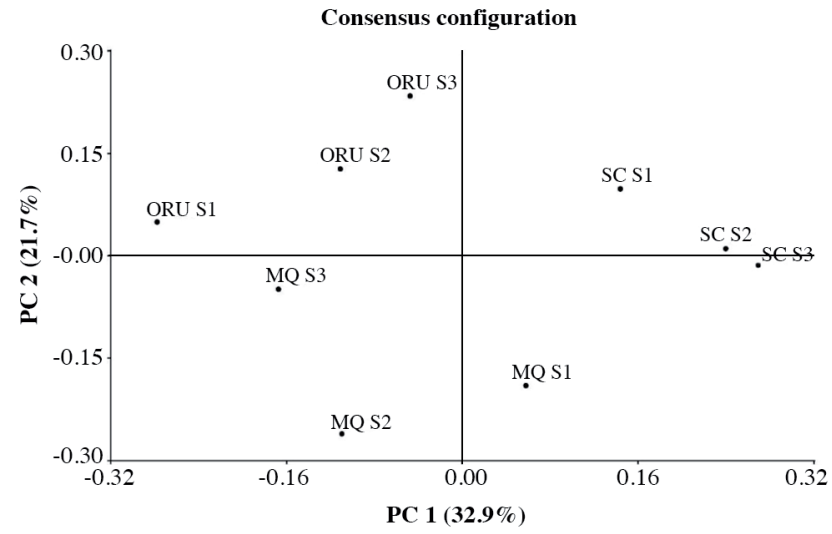

Table 6. Consensus between morphological and genetic analysis by the Procrustes method.

\begin{tabular}{lcccc}
\hline Populations & Residue & Total & ratio & Consensus \\
\hline SC S1 & 0.167 & 0.033 & 0.199 & 0.837 \\
SC S2 & 0.154 & 0.039 & 0.193 & 0.797 \\
SC S3 & 0.175 & 0.066 & 0.241 & 0.726 \\
MQ S1 & 0.153 & 0.038 & 0.191 & 0.802 \\
MQ S2 & 0.247 & 0.008 & 0.255 & 0.968 \\
MQ S3 & 0.135 & 0.039 & 0.174 & 0.778 \\
ORU S1 & 0.255 & 0.031 & 0.286 & 0.893 \\
ORU S2 & 0.181 & 0.017 & 0.198 & 0.916 \\
ORU S3 & 0.243 & 0.019 & 0.262 & 0.926 \\
\hline Total & 1.710 & 0.290 & 2.000 & 0.855 \\
\hline
\end{tabular}

SC: San Carlos, MQ: Manquehua, ORU: Oruro.

a trait of E. acida; however, populations of E. acida in this area with flowers exhibiting this dense mass of dark hairs have been observed. The objective of Medel (2000) was to find defense strategies against the parasite Tristerix aphyllus; a 2-yr follow-up of Echinopsis chilensis and E. acida was conducted in northern Chile and both species were found to have high synchrony in the flowering season, which occurs from September to mid-November. All of this reinforces the idea that the observed variability could be due to the co-existence with other species with simultaneous flowering, as was found in several species of the genus Hylocereus that have a high hybridization ability between them and with the species Selenicereus (Tel-Zur et al., 2004).

One of the highest $\mathrm{CV}$ values occurred for stem diameter; this trait could be strongly influenced by the age of the plant, which is a factor that cannot be controlled in wild populations. Therefore, its merit as a descriptor has been rejected in the present study. Other variables with high $\mathrm{CV}$ were the length of the shortest spine, areole length, and areole width. In the case of the length of the shortest spine, it could be related to an adaptive strategy to plant water stress and represent a local plasticity phenomenon; although these representative cactus structures are considered as a defense strategy, they can also accomplish ecological, reproductive, and physiological functions (Drezner, 2011). A study conducted on several traits of Pilosocereus arrabidae determined that the morphological variable correlations commonly used as descriptors could be highly plastic in accordance with the environment and should be used with caution (Menezes et al., 2015). The rest of the variables had $\mathrm{CV}$ values, ranging from 2.94 (number of ribs) to 38.66 (fruit sugar content), were not considered to be high.

Qualitative variables showed high variability, especially the flower variables with more than six phenotypes, which point them out as good descriptors for this species. Differences in fruit color and shape were significant for the three copao populations. Similar results were found by Jiménez-Aspee et al. (2014), who reported high variability in fruits collected at different locations in the Elqui and Limarí Valleys.

Principal component analysis resulted in the fruit variables forming a separate group from the rest of the variables under study (Figure 4) and almost all of them produced descriptors to differentiate between the San Carlos accessions vs. the Oruro and Manquehua accessions (Figure 5). Jiménez-Aspee et al. (2014) evaluated the functionality of fruits from the Elqui and Limarí Valleys and found differences between the high performance liquid chromatography (HPLC) patterns of both valleys. Plant variables allowed the separation of accessions between Oruro and Manquehua but to a lesser extent. In addition, conglomerate analysis per sector-population showed that the individuals of all the populations were different (Figure 5 ); it is therefore concluded that variability existed between and within the three wild copao populations and this variability could be determined using the morphological descriptors included in the present study. This result is relevant because no evaluation of the copao germplasm using neither morphological nor genetic traits has thus far been reported; this information is crucial for further studies with production and conservation purposes.

\section{Genetic diversity of copao populations}

The ISSRs proved to be powerful tools for studying variability in the three wild copao populations being analyzed. The percentage of polymorphic bands ranged from $70.0 \%$ with ISSR 08 to $90.9 \%$ with ISSR 02 along with high PIC values in the five markers, thus indicating good discriminant power and high diversity among the three copao populations. Similar results using ISSR obtained Ben et al. (2015) studying genetic diversity in wild cardoon (Cynara cardunculus L. var. sylvestris), with PIC values between 0.48 and 0.8 indicating a high level of microsatellite polymorphism in the studied population. Almajali et al. (2012) studied genetic diversity of Jordanian fig germplasm with ISSR markers, got PIC values between 0.25 and 030 indicating intermediate discriminating power. The present study is the first report about this species using these primers, and no information exists with which to compare previous research studies.

Cluster analysis of the genetic characterization showed fairly high Jacquard's distance coefficients between 0.50 
and 0.92 (mean 0.86), which indicate diversity between and within the populations in addition to the external group represented by E. breviflora (Figure 7). This reinforces the results obtained from the morphological analysis of the diversity between and within the populations, but includes additional information showing the similarity between two sectors of the San Carlos population that the morphological analysis could not detect; this could be a criterion to support the use of both markers.

\section{Consensus between molecular and morphological systems}

Based on separate results between morphological traits and ISSR analysis, both types of markers were consistent but especially when analyzing the consensus between $(85 \%)$ using GPA. Bramardi et al. (2005) found similar result in agronomic and molecular characterization of cucumber genotypes using this method and pointing this technique as a powerful tool for establishing agreement between simultaneous studies. Both variables in parallel form have a greater discrimination power than the alone techniques. Finally, the variability founded in this species can help to identify the parameters required to initiate a program for its domestication and breeding for production or conservation purposes.

\section{CONCLUSIONS}

Diversity existed between and within the copao endemic populations found in San Carlos, Oruro, and Manquehua, which was evaluated through morphological descriptors of the fruit, flowers, or plant indicated for other columnar cacti, ISSR markers were also used.

The morphological descriptors used in this investigation allowed us to study the variability between and within the wild copao populations in which high phenotypic diversity was observed. Many of them, especially those associated with the fruits, could be economically important traits if production of this species continues to develop in Chile; they could be used as productivity selection traits in a breeding program.

The ISSR markers provided much information for discriminating copao germplasm and were a powerful tool to analyze the diversity of this species. These markers can provide basic information needed to generate a gene bank and conserve materials from different populations.

The consensus between both methods indicates that they can be used as a complement for developing a collection that could rely on the genetic resource for both breeding and conservation purposes.

\section{ACKNOWLEDGEMENTS}

This study was financed by INNOVA-Corfo Chile through the project $\mathrm{N}^{\circ} 11 \mathrm{BPC}-9960$.

\section{REFERENCES}

Almajali, D., Abdel-Ghani, A., and Migdali, H. 2012. Evaluation of genetic diversity among Jordanian fig germplasm accessions by morphological traits and ISSR markers. Scientia Horticulturae 124:294-297.

Badano, E., y Schlumpberger, B. 2001. Sistema de cruzamiento y estimaciones en la eficiencia de polinización sobre Trichocereus pasacana (Cactaceae) en dos poblaciones del noroeste argentino. Gayana Botánica 58:115-122.

Ben, I., Sonnante, G., and Al Mohandes, B. 2015. Genetic variability in wild cardoon (Cynara cardunculus L. var. sylvestris) revealed by SSR markers and morphological traits. Scientia Horticulturae 185:76-81.

Bianco, C., Fernández, J., Migliaro, D., Crinó, P., and EgeaGilbert, C. 2011. Identification of F1 hybrids of artichoke by ISSR markers and morphological analysis. Molecular Breeding 27:157-170.

Bornet, B., and Branchard, M. 2001. Nonanchored inter simple sequence repeat (ISSR) markers: reproducible and specific tools for genome fingerprinting. Plant Molecular Biology Reporter 19:209-215.

Bramardi, S., Bernet, G., Asíns, M., and Carbonell, E. 2005. Simultaneous agronomic and molecular characterization of genotypes via the Generalized Procrustes Analysis: An application in cucumber. Crop Science 45:1603-1609.

Campos-Rojas, E., Pinedo-Espinoza, J., Campos-Montiel, R., y Hernández-Fuentes, A. 2011. Evaluación de plantas de Pitaya (Stenocereus spp.) de poblaciones naturales de Monte Escobedo, Zacatecas. Revista Chapingo Serie Horticultura 17:173-182.

Cares, R., Muñoz, P., Medel, R., and Botto, C. 2013. Factors affecting cactus recruitment in semiarid Chile: A role for nurse effects? Flora 208:330-335.

Casas, A., Otero, A., Pérez, E., and Valiente, A. 2007. In situ Management and domestication of plants in Mesoamerica. Annals of Botany 100:1101-1115.

Castro-Félix, P., Muñoz, A., Torres, I., Palomera-Ávalos, V., y Santerre, A. 2008. Análisis de marcadores ISSRs e ISTRs en genoma de Ferocactus histrix. Avances en Investigación Científica en el CUCBA 19:399-405.

Clark-Tapia, R., Alfonso-Corrado, C., Eguiarte, L., and MolinaFreaner, F. 2005. Clonal diversity and distribution in Stenocereus eruca (Cactaceae), a narrow endemic cactus of the Sonoran Desert. American Journal of Botany 92:272-278.

Cota-Sánchez, J., Remarchuk, K., and Bayasena, K. 2006. Ready to use DNA extracted with a CTAB method adapted for herbarium specimens and mucilaginous plant tissue. Plant Molecular Biology Reporter 24:161-167.

Drezner, T. 2011. Cactus surface temperatures are impacted by seasonality, spines, and height on plant. Environmental and Experimental Botany 74:17-21

Ferreira, J., Garcia-Gonzalez, C., Tous, J., and Rovira, M. 2010. Genetic diversity revealed by morphological traits and ISSR markers in hazelnut germplasm from northern Spain. Plant Breeding 129:435-441.

Franco, T., e Hidalgo, R. (eds.) 2003. Análisis estadístico de datos de Caracterización morfológica de recursos fitogenéticos. Boletín Técnico $\mathrm{N}^{\circ} 8.89$ p. Instituto Internacional de Recursos Fitogenéticos (IPGRI), Cali, Colombia.

Gower, J., and Ross, G. 1969. Minimum spanning trees and single linkage cluster analysis. Journal of the Royal Statistical Society. Series C (Applied Statistics) 18:(1)54-64. 
Hernández-Villareal, A. 2013. Caracterización morfológica de recursos fitogenéticos. Revista Biociencias 2:113-118.

Hoffmann, A., y Walter, H. 2004. Cactáceas en la flora silvestre de Chile. Segunda edición revisada y aumentada. 307 p. Fundación Claudio Gay, Santiago, Chile.

Hoxey, P., and Klaassen, P. 2011. Two new combinations in the genus Eulychnia (Cactaceae). Cactus and Succulent Journal 83:169-175.

Di Rienzo J., Casanoves, F., Balzarini, M., Gonzalez, L., Tablada, M. y Robledo, C. 2008. InfoStat, versión 2008. Grupo InfoStat, FCA, Universidad Nacional de Córdoba, Argentina.

Jiménez-Aspee, F., Alberto, M.R., Quispe, C., del P Soriano, M., Theoduloz, C., Zampini, I.C., et al. 2015. Anti-inflammatory activity of copao (Eulychnia acida Phil., Cactaceae) fruits. Plant Foods Humane Nutrition 70(2):135-140. doi:10.1007/s11130015-0468-7.

Jiménez-Aspee, F., Quispe, C., Soriano, M., Fuentes, J., Hüneke, E., Theoduloz, C., et al. 2014. Antioxidant activity and characterization of constituents in copao fruits (Eulychnia acida Phil., Cactaceae) by HPLC-DAD-MS/MSn. Food Research International 62:286-298.

Keb-Llanes, M., Gonzalez, G., Chi-Manzanero, B., and Infante, D. 2002. A rapid and simple method for small-scale DNA extraction in Agavaceae and other tropical plants. Plant Molecular Biology Reporter 20:290-299.

Lodhi, M.A., Ye, G.N., Weeden, N.F., and Reisch, B.I. 1994. A simple and efficient method for DNA extraction from grapevine cultivars and Vitis species and Ampelopsis. Plant Molecular Biology Reporter 12:6-13.

Luna-Paez, A., Valadez-Moctezuma, E., Barrientos-Priego, A., and Gallegos-Vázquez, C. 2007. Characterization of Opuntia spp. by means of seed with RAPD and ISSR markers and its possible use for differentiation. Journal of the Professional Association for Cactus Development 9:43-81.

Masson, L., Salvatierra, A., Robert, P., Encina, C., and Camilo, C. 2011. Chemical and nutritional composition of copao fruit (Eulychnia acida Phil.) under three environmental conditions in the Coquimbo Region. Chilean Journal of Agricultural Research 71:521-529.

Medel, R. 2000. Assessment of parasite-mediated selection in a host-parasite system in plants. Ecology 81:1554-1564.

Medel, R., Méndez, M., Ossa, C., and Botto, C. 2010. Arms race coevolution: the local and geographical structure of a hostparasite interaction. Evolution Education and Outreach 3:26-31.

Menezes, M., Taylor, N., Zappic, D., and Loiola, M. 2015. Spines and ribs of Pilosocereus arrabidae (Lem.) Byles \& G.D. Rowleyand allies (Cactaceae): Ecologic or genetic traits? Flora 214:44-49.

Munsell Color. 1977. Munsell color chart for plant tissues. Munsell Color, Baltimore, Maryland, USA.

Oleas, N., Von Wettber, E.J., and Negrón-Ortiz, V. 2014. Population genetics of the Federally Threatened Miccosukee gooseberry (Ribes echinellum), an endemic North American species. Conservation Genetics 15:749-755.

Roldán-Ruiz, I., Dendauw, J., Van Bockstaele, E., Depicker, A., and De Loose, M. 2000. AFLP Markers reveal high polymorphic rates in ryegrasses (Lolium spp.) Molecular Breeding 6:125-135.

Rosales-Bustamante, E.P., C. del C. Luna-Morales, y A. CruzLeón. 2009. Clasificación y selección tradicional de pitaya (Stenocereus pruinosus (Otto) Buxb.) en Tianguistengo, Oaxaca y variación morfológica de cultivares. Revista Chapingo. Serie Horticultura 15:75-82.

Royal Horticultural Society. 2014. RHS mini color chart. Royal Horticultural Society (RHS), London, UK; Flower Council of Holland, Leiden, The Netherlands.

Sheth, S., and Angert, A. 2014. The evolution of environmental tolerance and range size: a comparison of geographically restricted and widespread Mimulus. Evolution 68:2917-2931.

Tao, J., Qiao, G., Peng, X., Li, G., Liu, T., Peng, Z., et al. 2014. Characterization of genetic relationship of dragon fruit accessions (Hylocereus spp.) by morphological traits and ISSR markers. Scientia Horticulturae 170:82-88.

Tel-Zur, N., Abbo, S., Bar-Zvi, D., and Mizrahi, Y. 2004. Genetic relationships among Hylocereus and Selenicereus vine cacti (Cactaceae): Evidence from hybridization and cytological studies. Annals of Botany 94:527-534.

Zietkiewicz, E., Rafalski, A., and Labuda, D. 1994. Genome fingerprinting by simple sequence repeat (SSR)-anchored polymerase chain reaction amplification. Genomics 20:176-183. 